\title{
Clinical and histopathological study of the phototoxic dermatitis in Zebu calves in grazing of Brachiaria decumbens
}

\author{
Estudio clínico e histopatológico de la dermatitis fototóxica en \\ terneros Cebú en pastoreo de Brachiaria decumbens
}

\author{
José Cardona-Álvarez, ${ }^{1 *}$ Ph.D, Marlene Vargas-Vilória, ${ }^{2}$ Ph.D, \\ Enrique Paredes-Herbach, ${ }^{3}$ Ph.D.
}

\begin{abstract}
${ }^{1}$ Universidad de Córdoba, Departamento de Ciencias Pecuarias, Grupo de Estudios e Investigaciones en Medicina de Grandes Animales (MEGA), Montería, Colombia. ${ }^{2}$ Universidad Federal de Viçosa, Departamento de Medicina Veterinaria, Viçosa, Brasil. ${ }^{3}$ Universidad Austral de Chile, Facultad de Ciencias Veterinarias, Instituto de Patología Animal, Valdivia, Chile. *Correspondence: cardonalvarez@ hotmail.com
\end{abstract}

Received: May 2015; Accepted: December 2015.

\section{RESUMEN}

Objetivo. El objetivo del trabajo fue estudiar los aspectos clínicos e histopatológicos de la Dermatitis Fototóxica Secundaria (DFS), debidos a la ingestión de Brachiaria decumbens en terneros cebú (Bos indicus) del departamento de Córdoba, Colombia. Materiales y métodos. Se estudiaron doce terneros Cebú, machos, de 12 a 18 meses de edad, con DFS diagnosticados clínica, histopatológicamente y exámenes de laboratorio. Resultados. Clínicamente, se evidenciaron signos de fotofobia, deshidratación, emaciación progresiva, mucosas ictéricas y lesiones cutáneas como res-quebramiento de la piel con aspecto apergaminado, desprendimiento cutáneo y formación de costras en grandes extensiones. Las lesiones se ubicaron bilateralmente en diferentes áreas de la piel en orejas, región perineal, epigástrica y costal. La pruebas serológicas arrojaron elevada actividad catalítica de las enzimas hepáticas GGT y AST indicando lesión hepática compatible con colestasis. Histopatológicamente, se observó en hematoxilina eosina, dermatitis necrótica crónica, en tricrómico de gómori, se observó escasa proliferación dérmica de fibroblastos desorganizados, escasa presencia de tejido conjuntivo difuso y fibras de colágeno desorganizadas y en picrosirius red/polarización, se observó áreas de birrefringencia rojiza y verde-amarillenta, indicando moderada presencia de colágeno maduro tipo I (color rojo brillante en la polarización) y de tipo III (color verde-amarillento brillante en la polarización). Conclusiones. El diagnóstico definitivo de la enfermedad se fundamentó en las características clínicas, en los resultados de laboratorio y en los hallazgos histopatológicos, siendo concluyentes como métodos de diagnóstico de la DFS. En la literatura consultada no existen reportes de estudios de DFS en terneros Cebú del departamento de Córdoba y en Colombia.

Palabras clave: Bovinos, fotosensibilización hepatógena, intoxicación alimentaria, intoxicación por plantas, (Fuente: MeSh).

\section{ABSTRACT}

Objective. The objective was to study the clinical and histopathological aspects of Phototoxic Dermatitis Secondary (PDS), secondary to ingestion of Brachiaria decumbens in Zebu calves (Bos indicus) department of Cordoba, Colombia. Materials and methods. Twelve calves Zebu, male, 12 to 18 months, PDS diagnosed with clinical, histopathologically studied and laboratory exams. Results. 
Clinically, signs of photophobia, dehydration, progressive emaciation, icteric mucous membranes and skin lesions as res-breaking with leathery skin appearance, skin peeling and scabbing over large areas were evident. The lesions were located bilaterally in different areas of the skin in ears, perineal region, epigastric and costal. Serological tests gave the high catalytic activity of the liver enzymes AST and GGT indicating liver injury consistent with cholestasis. Histopathologically was observed in hematoxylin eosin, chronic necrotic dermatitis, in trichrome Gomori poor dermal proliferation disorganized fibroblasts, low presence of diffuse connective tissue and collagen fibers disorganized and picrosirius red / polarization areas reddish birefringence was observed was observed and greenyellow, indicating moderate presence of mature collagen type I (bright red in polarization) and Type III (bright yellowish-green polarization). Conclusions. The definitive diagnosis of the disease was based on clinical features, laboratory findings and histopathological findings, being conclusive as diagnostic methods of the PDS. In the literature there are no reports of studies PDS in Zebu calves department of Córdoba and Colombia.

Key words: Bovine, food poisoning, hepatogenous photosensitization, plant poisoning (Source: MeSh).

\section{INTRODUCTION}

Phototoxic dermatitis (DFS), also known as hepatogenic or secondary photosensitization, is defined as skin sensitivity to sunlight due to the presence of photodynamic agents (1) in severe cases of photosensitive dermatitis. It is known in Brazil as "requeima" (2) and in Colombia it is known on the Atlantic coast as "fiebre candela" and in the Andean region as "Brasa, lamparón or fiebrón" (3). It has been reported in different species; however, the largest presentation of casuistry has been reported in ruminants, including reports for sheep (4-6), goats (7), buffalo $(8,9)$ and bovines (2.10). Also, greater susceptibility is reported in sheep than in cattle (7), and it mostly affects young animals rather than in adults (11).

The presence of photodynamic substances produced by higher plants that are reactive to light can lead to significant damage to sensitive tissues and can cause irritation, abrasion and secondary skin infections (12). DFS occurs when hepatotoxic substances, whether chemical factors (phenothiazine, tetracycline or sulfonamide) or biological factors (toxic plants or infectious agents like the fungus Phytomices chartarum) cause sufficient damage the liver to prevent excretion of photoactive phytoporphyrins (13).

An important photodynamic agent is phylloerythrin, produced by chlorophyll decomposition, which accumulates in significant concentrations in the blood flow of affected animals, thereby inducing photosensitivity. Phylloerythrin occurs as a normal byproduct of rumen function, when large amounts of chlorophyll are decomposed by bacteria in the gastrointestinal tract and are absorbed through the rumen into the bloodstream where

\section{INTRODUCCIÓN}

La dermatitis fototóxica secundaria (DFS), también conocida como fotosensibilización hepatógena o secundaria, se define como la sensibilidad de la piel a la luz solar debido a la presencia de agentes fotodinámicos (1), por la presentación marcada en casos graves de dermatitis fotosensible es conocida en Brasil como "requeima" (2) y en Colombia es conocida en la costa atlántica como "fiebre candela" y en la región andina como "Brasa, lamparón o fiebrón" (3). Ha sido reportada en diferentes especies; sin embargo, la mayor presentación de casuística se ha reportado en rumiantes, entre las cuales existen informes de presentación en ovinos (4-6), caprinos (7), bufalinos $(8,9)$ y bovinos $(2,10)$, de igual forma, se reporta mayor susceptibilidad en ovinos que en bovinos (7), así como la mayor presentación en animales jóvenes que en adultos (11).

La presencia de sustancias fotodinámicas reactivas a la luz, producidas por las plantas superiores puede dar lugar a daños considerables en los tejidos sensibles, causando irritación, abrasión e infección secundaria de la piel (12). La DFS ocurre cuando sustancias hepatotóxicas, ya sea factores químicos (fenotiazinas, tetraciclinas o sulfonamidas), o factores biológicos (plantas tóxicas o agentes infecciosos como el hongo Phytomices chartarum) lesionan el hígado de forma suficiente para impedir a excreción de fitoporfirinas fotoactivas (13).

Un agente fotodinámico importante es la filoeritrina, que es el producto de la descomposición de la clorofila, que se acumula en concentraciones significativas en el flujo sanguíneo de los animales afectados, induciendo de ese modo la fotosensibilidad. La filoeritrina se produce como subproducto normal de la función ruminal, cuando grandes cantidades de clorofila son descompuestas por bacterias en el tracto gastrointestinal, éstas se absorben a través del rumen al torrente 
they are removed by conjugation and excretion in bile (12). When they are not eliminated by an injured liver, phylloerythrin concentrations increase in blood circulation and then accumulate in the skin. Since this is a photodynamic agent, it absorbs certain ultraviolet wavelengths (UV), becomes active, and transmits this extra energy to the circumjacent cells, which results in cell injury (14).

Scheie et al (15), in studies on sheep, established normal phylloerythrin plasma concentrations at less than $0.01 \mathrm{mM} / \mathrm{L}$, and estimated values superior to $0.03 \mathrm{mM} / \mathrm{L}$ as sufficient for photosensitization to take place in affected animals. Although how phylloerythrin acts as a photodynamic agent is unknown, studies have shown that it binds to Golgi and mitochondria, indicating that these organelles may be the main target of this phototoxic compound (12).

Over the years, the toxic power of Brachiaria spp. was added to the concomitant action of the fungus Phytomices chartarum, which synthesizes and releases esporodesmin through its spores, which causes liver injury. This mycotoxin belongs to the class of epipolythiodioxypiperazine toxic compounds and is considered highly hepatotoxic and causes in the host a hepatocyte immune response mediated by foamy macrophages, which when swallowed form "digestion chambers" that occlude bile ducts and impede phylloerythrin excretion with subsequent photosensitization. However, studies on photosensitive animals grazing in paddocks with Brachiaria showed very low amounts of $P$. chartarum fungal spores and with no sporidesmin production, so it was concluded that such cases were not due to the presence of the fungus, but to toxic conditions of Brachiaria components (16).

Quinn et al (12) showed that secondary skin photosensitization due to liver impairment could be influenced by the presence of lithogenic steroidal saponin present in Brachiaria spp. pastures. Wina et al (17) explain that although saponin is not essential to the life of the plant, it ensures survival in the ecosystem, located in the most vulnerable parts of the plant to fungal and bacterial attack or predator insects, and are related to the defense mechanism of the plant by acting as a protective chemical barrier.

A large number of hepatotoxins derived from plants have been reported, including steroid saponins, terpenes and tannins which can also cause death through acute liver failure. However, if they are ingested in smaller sanguíneo donde se elimina vía hepática por el mecanismo de conjugación y excreción en la bilis (12). De tal manera que al no ser eliminada por el hígado lesionado, las concentraciones de filoeritrina aumentan en la circulación sistémica y posteriormente se acumulan en la piel y siendo este un agente fotodinámico absorbe ciertas longitudes de onda de luz ultravioleta (UV), tornándose activa y transmitiendo esta energía extra hacia las células circunyacentes; resultando en lesión celular (14).

Scheie et al (15), en estudios realizados en ovinos establecieron como concentraciones plasmáticas normales de filoeritrina valores inferiores a 0.01 $\mathrm{mM} / \mathrm{L}$, y estimaron que valores superiores a $0.03 \mathrm{mM} / \mathrm{L}$ son suficientes para que se instaure la fotosensibilización en los animales afectados. Aunque el modo de acción de filoeritrina como agente fotodinámico es desconocido, los estudios han demostrado que se une al aparato de Golgi y a las mitocondrias; indicando que estos orgánulos pueden ser el blanco principal de este compuesto fototótoxico (12).

A lo largo de los años, fue adjudicado el poder tóxico de las Brachiaria spp., a la acción concomitante del hongo Phytomices chartarum, que sintetiza y libera a través de sus esporas la toxina esporodesmina causante de lesión hepática, ésta micotoxina pertenece al grupo de compuestos tóxicos epipolitiadioxipiperazina y es considerada altamente hepatotóxica, y ocasiona en el hospedero una respuesta inmunológica en los hepatocitos mediada por macrófagos espumosos, que al ser fagocitadas por éstos, forman "cámaras de digestión" que ocluyen los ductos biliares; impidiendo la excreción de la filoeritrina con la consecuente fotosensibilización. Sin embargo, estudios realizados en animales con fotosensibilización que pastaban en potreros de Brachiaria, contenían cantidades muy bajas de esporas de hongo $P$. chartarum y sin producción de esporodesmina, por lo que se concluyó que esos casos no se debían a la presencia del hongo, pero si a las condiciones tóxicas de los componentes de la Brachiaria (16).

Quinn et al (12), manifestaron que la fotosensibilización cutánea secundaria a alteraciones hepáticas podría estar influenciada por la presencia de saponinas esteroidales litogénicas presentes en los pastos Brachiaria spp., Wina et al (17), explican que a pesar de que la saponina no es esencial para la vida de la planta productora, garantiza su supervivencia en su ecosistema, ya que se ubican en las partes de más vulnerables de la planta al ataque fúngico, bacteriano o predador de los insectos, estando relacionadas con el sistema de defesa de la planta al actuar como barrera química y protectora. 
doses that the animal survives, subsequent liver alterations may result in secondary photosensitization. Thus, Riet-Correa et al (7) reported that Brachiaria spp. pastures have varying degrees of toxicity associated with saponin levels, indicating that protodioscin (saponins in Brachiaria decumbens), that when hydrolyzed form sapogenin, diosgenin and yamogenin. When metabolized in the digestive tract, epismilagenin and episarsasapogenin sapogenins are formed that combine with glycoronic acid, forming glycuronides that bind calcium ions and form insoluble salts that are deposited as crystals. Oliveira et al (9), Faccin et al (14), and Santos et al (18) demonstrated that these lithogenic steroidal saponins present in the Brachiarias spp. induce migration of foamy macrophages and stimulate the formation of crystals in hepatocytes and bile ducts, obstructing bile canaliculi with the consequent accumulation of phylloerythrin in circulation and in the skin, which causes phototoxic dermatitis.

Clinical manifestations begin with loss of appetite, excitability, pruritus, bilateral epiphora, cutaneous edema on ears, chin, flanks, and cauda and inguinal folds. In most cases the animal manifests photophobia $(5,13)$, and as the disease progresses this becomes more pronounced and is considered a sign of photosensitivity. Mucous membranes become jaundiced, the animal becomes dehydrated, with progressive emaciation due to loss of appetite that increases and even reaches cachectic state, pronounced skin wrinkling especially around the ears and perineal and costal regions $(13,18)$. Injuries are primarily in areas most exposed to the sun, especially where there is less pigmentation or lower fur density such as eyelids, ears, perineum and dorsal and erythema and edema begin, and later the formation of vesicles, exudation, necrosis and desquamation (7).

It is important to use blood tests to evaluate the catalytic activity of liver enzymes, particularly GGT (Gamma Glutamyl Transferase) and AST (Aspartate Amino transaminase), since a significant increase in serum is indicative of hepatic impairment, especially GGT, which is located at the canaliculi hepatic level (4-6).

In histopathology, hematoxylin eosin coloring in the affected skin can be observed epithelial degeneration with vacuolar degeneration, chronic necrotizing dermatitis and necrosis in the epidermal layer and edema in the dermal as well as macrophage infiltration and fibrinoid degeneration in the middle arteries (4). Focal
Se ha reportado un gran número de hepatotoxinas derivadas de plantas, entre las que se incluyen las saponinas esteroides, terpenos y taninos que también pueden causar la muerte a través de la insuficiencia hepática aguda; sin embargo, si éstos se ingieren en dosis más pequeñas de modo que el animal sobrevive a la injuria hepática inicial, subsiguientes alteraciones hepáticas pueden resultar en fotosensibilización secundaria. Es así como, Riet-Correa et al (7), informaron que los pastos Brachiaria spp., presentan grados variables de toxicidad asociada a los niveles de saponina, indicando que las protodioscinas (saponinas presentes en la Brachiaria decumbens), cuando son hidrolizadas resultan en sapogenina, diosgenina y yamogenina, que al pasar por el metabolismo en el tracto digestivo de los animales, se forman las sapogeninas epismilagenina y episarsasapogenina que se conjugan con el ácido glicorónico, formando glicuronídeos que se unen a los iones de calcio y forman sales insolubles que se depositan en forma de cristales. Oliveira et al (9) y Faccin et al (14), Santos et al (18), manifestaron que estas saponinas esteroidales litogénicas presentes en las Brachiarias spp., inducen la migración de macrófagos espumosos y estimulan la formación de cristales en los hepatocitos y ductos biliares; obstruyendo los canalículos biliares con la consecuente acúmulo de filoeritrina en la circulación y en la piel, causando la dermatitis fototóxica.

Las manifestaciones clínicas inician con inapetencia, excitabilidad, prurito, epifora bilateral, edema cutáneo a nivel de orejas, papada, flancos, pliegues caudales e inguinales y en la mayoría de los casos comienza a manifestarse fotofobia $(5,13)$, en la medida que avanza la enfermedad, la fotofobia se hace mayor por lo que ya es considerada signo de fotosensibilización, las mucosas se tornan ictéricas, deshidratación, la emaciación progresiva debido a la inapetencia cada vez es mayor que incluso llegan a estados caquéxicos, arrugamiento marcado de la piel, especialmente en las orejas, región perineal y costal $(13,18)$. La lesiones se presentan principalmente en las áreas de mayor exposición solar, especialmente las de menos pigmentación o pelaje de menor densidad como parpados, orejas, región perineal y dorsal, comienza eritema y edema, posteriormente se forman vesículas, exudación, necrosis y descamación (7).

Es importante la realización de pruebas sanguíneas, con el fin de evaluar la actividad catalítica de las enzimas hepáticas, en particular la GGT (Gamma Glutamil Transferasa) y la AST (Aspartato Amino Transaminasa), ya que un aumento considerable de las concentraciones séricas son indicadoras de alteración hepática, en especial la GGT que se ubica a nivel de los canalículos hepáticos (4-6). 
chronic periportal hepatitis can be found, with numbness and retention in hepatocytes and bile canaliculi, as well as increased neutrophils in the liver parenchyma, presence of macrophages with negative cytoplasmic images of acutiforme crystals and foamy cytoplasm in the interior of the sinusoids and periportal region, respectively. Similarly, bile duct hyperplasia can be observed and the presence of crystalloid birefringent that occludes bile ducts $(5,9)$.

Treatment consists of immediate removal of the animals from pastures with Brachiaria spp. and sunny areas, and applying liver protectors, anti-histamines and moisturizing solutions as well as using antiseptics and healing ointments on the worst lesions. Another alternative is the use of dexamethasone acetate and vitamin B complex, and both treatments may have favorable results depending on the exposure time and extent of liver damage (19).

The aim of this study was to conduct a study on the clinical and histopathological aspects of DFS in twelve Zebu calves department of Cordoba, Colombia.

\section{MATERIALS AND METHODS}

Type of study. A descriptive type study was done, non-probalistic in animals with cutaneous lesions compatible with DFS.

Location. It was conducted between February and March in the department of Córdoba, Colombia, located between coordinates $7^{\circ} 23^{\prime}$ and $9^{\circ} 26^{\prime} \mathrm{NL}$ and $74^{\circ} 52^{\prime}$ and 76032' WL of Greenwich, at a height of $30 \mathrm{~m}$ with average annual temperature of $28^{\circ} \mathrm{C}$, relative humidity $82 \%$, annual rainfall $1400 \mathrm{~mm}$ in a rainforest climate (20).

Study animals. Twelve male Cebu calves with an average age of 12 to 18 months were used. All showed signs of photophobia, dehydration, progressive emaciation, jaundiced mucous membranes and skin lesions such as cracked skin with leathery appearance around the ears, perineal, epigastric and costal regions and peeling skin with some scabbing, symptoms compatible with DFS.

Methodology. All animals underwent clinical evaluation and histopathological characterization of skin lesions, for which high definition photographs for further analysis (DSC-HX10V Sony, China) were taken. Similarly, after sedation (acepromazine
En la histopatología, en la coloración de hematoxilina eosina, se puede observar a nivel de regiones afectadas de la piel, degeneración epitelial con degeneración vacuolar, dermatitis necrótica crónica y necrosis en la capa epidérmica, así como en la dermis se observa edema, infiltración de macrófagos y degeneración fibrinoide en las arterias medias (4). A nivel hepático se puede encontrar hepatitis periportal crónica focal con entumecimiento y retención en los hepatocitos y canalículos biliares, así como aumento de los neutrófilos en el parénquima hepático, presencia de Macrófagos con imágenes negativas citoplasmáticas de cristales acutiformes y citoplasma de aspecto espumoso en el interior de los sinusoides y en la región periportal respectivamente. De igual forma, se puede observar hiperplasia de ductos biliares y presencia de material cristaloide birrefringente ocluyendo la luz de ductos biliares $(5,9)$.

El tratamiento, consiste en la retirada inmediata de los animales de los potreros con Brachiaria spp y sitios soleados, aplicación de protectores hepáticos, anti-histamínicos y soluciones hidratantes, así como el uso de pomadas antisépticas y cicatrizantes en las lesiones más marcadas, otra alternativa farmacológica es el uso de acetato de dexametasona y complejo vitamínico B, ambos tratamientos pueden resultar favorables dependiendo del tiempo de exposición y del comprometimiento hepático (19).

El objetivo de este trabajo fue realizar un estudio sobre los aspectos clínicos e histopatológicos de la DFS en doce terneros cebuínos del departamento de Córdoba, Colombia.

\section{MATERIALES Y MÉTODOS}

Tipo de estudio. Se realizó un estudio de tipo descriptivo, no probabilístico en animales de conveniencia con presencia de lesiones cutáneas compatibles con DFS.

Localización. Fue realizado entre los meses de febrero y marzo en el departamento de Córdoba, Colombia, ubicado entre las coordenadas $7^{\circ} 23^{\prime}$ y $9^{\circ} 26^{\prime}$ LN y los $74^{\circ} 52^{\prime}$ y $76^{\circ} 32^{\prime}$ LO del meridiano de Greenwich, a una altura de 30 m.s.n.m, con temperatura promedio anual de $28^{\circ} \mathrm{C}$, humedad relativa del $82 \%$, precipitación media anual de 1400 $\mathrm{mm}$ y pertenece a la formación climática de bosque tropical lluvioso (20).

Animales de estudio. Se utilizaron doce terneros Cebú, machos, con edad promedio de 12 a 18 meses, los cuales presentaron signos de fotofobia, deshidratación, emaciación progresiva, mucosas ictéricas y lesiones cutáneas como res-quebramiento 
$1 \%$, Zoo, Colombia) and application of local anesthesia (Lidocaine $2 \%$, Synthesis, Colombia), excisional biopsy of tissue from the periphery of the skin lesion was performed and fixed in $10 \%$ formalin ( $/ \mathrm{v}$ ) (9) and taken to the Pathology laboratory of the department of Animal Sciences at the University of Cordoba, Colombia, where they were processed to inclusion in paraffin. Subsequently, they were transferred to the laboratory of Structural Biology in the department of General Biology at the Federal University of Viçosa, Brazil, where they were processed for routine histopathologic evaluation, cut to $5 \mu \mathrm{m}$ on a microtome (Leica RM2125 RTS, Japan) and stained with hematoxylin-eosin (HE), Gomori trichrome ( $T$ G) and Picrosirius Red/Polarization (PR/P). For microscopic photo analysis of the samples, a microscope with polarization options (Olympus BX-53 ${ }^{\circledR}$, Brazil) was used from the Molecular Systematics Laboratory/BEAGLE of the Animal Biology Department of the Federal University of Viçosa, Brazil.

$10 \mathrm{ml}$ blood samples were collected without anticoagulant by venipuncture of the jugular using a vacuum collection system to obtain serum from the twelve animals with DFS and six other clinically healthy animals from the lot as the sick animals to perform biochemical tests for liver and kidney function. Each sample was labeled and stored in refrigeration at $4^{\circ} \mathrm{C}$ (Plastic Refrigerator, Imusa, Colombia) to be later taken to the "Cereté" Clinical Laboratory in the municipality of Cereté, Córdoba, where GGT and AST serum levels were determined to evaluate liver function as well as urea and creatinine to assess renal function (14).

After clinical evaluation, injury characterization, and sampling, a therapeutic strategy was instituted consisting of suspending the gentian violet treatment that had been applied which potentiates sunlight, as well as immediately removing the animal from the Brachiaria decumbens paddock to one with Dychanthium aristatum grass and shade provided by trees and shade structures. Likewise, a corticoid-based dexamethasone was applied at a dose of $0.1 \mathrm{mg} / \mathrm{kg}$ intramuscularly and 10 centimeters of a commercial B complex multivitamin intramuscularly for 5 days, as well as administering a hydrating solution consisting of a mixture of molasses with sodium bicarbonate.

Ethical aspects. The animals were not subjected to pain an or unnecessary stress, and were immobilized taking into account the technical standards in handling and restraining de la piel con aspecto apergaminado a nivel de orejas, región perineal, epigástrica y costal, así como desprendimiento cutáneo en algunas áreas con formación de costra, siendo estas manifestaciones compatibles con DFS.

Metodología. A todos los animales se les realizó evaluación clínica y caracterización anatomopatológica de las lesiones cutáneas, para lo cual se tomaron fotografías de alta definición para su posterior análisis (Sony DSC-HX10V, China). De igual forma, previa sedación (Acepromacina $1 \%$, Zoo, Colombia) y aplicación de anestesia local (Lidocaina $2 \%$, Synthesis, Colombia) fueron realizadas biopsias excisionales de tejido desde la periferia de la lesión cutánea, siendo fijadas en formol al $10 \%(\mathrm{v} / \mathrm{v})$, (9) y llevadas al laboratorio de Patología del departamento de Ciencias Pecuarias de la Universidad de Córdoba, Colombia, donde fueron procesadas hasta su inclusión en parafina, posteriormente trasladadas al laboratorio de Biología Estructural del departamento de Biología General de la Universidad Federal de Viçosa, Brasil, donde fueron procesadas para la rutina de evaluación histopatológica, cortadas a $5 \mu \mathrm{m}$ de espesor en un micrótomo (Leica RM2125 RTS, Japón) y teñidas con las coloraciones de Hematoxilina - Eosina $(\mathrm{H}-\mathrm{E})$, Tricrómico de Gómori (T-G) y Picrosirius Red/Polarization $(P-R / P)$. Para el análisis foto microscópico de las muestras, fue utilizado un microscopio con opción de polarización (Olympus BX-53 ${ }^{\circledR}$, Brasil) del laboratorio de Sistemática Molecular/BEAGLE del departamento de Biología Animal de la Universidad Federal de Viçosa, Brasil.

Fueron colectadas muestras de sangre de $10 \mathrm{ml}$ sin anticoagulante a través de veno-punción de la yugular utilizando sistema de colecta al vacío, para obtención de suero, de los doce animales con DFS y de otros seis animales clínicamente sanos pertenecientes al mismo lote de los enfermos para realización de pruebas bioquímicas de función hepática y renal. Cada muestra, se rotuló y se conservó en refrigeración a $4^{\circ} \mathrm{C}$ (Nevera Plástica, Imusa, Colombia), para posteriormente ser llevada al Laboratorio Clínico "Cereté" del municipio de Cereté, Córdoba, donde fueron determinados los niveles séricos de GGT y AST para evaluación de la función hepática y de urea y creatinina para evaluación de la función renal (14).

Posterior a la evaluación clínica, caracterización de lesiones y toma de muestras, fue instaurada una estrategia terapéutica consistente en la suspensión del tratamiento que se venía aplicando con violeta de genciana la cual potenciaba la acción de los rayos solares, así como la retirada inmediata del potrero de Brachiaria decumbens a uno de pasto Dychanthium aristatum con sombras proporcionadas por árboles y la colocación de polisombras, de igual forma, se les 
animals in compliance with the Universal Declaration of Animal Rights concerning international biomedical research with animals CIOMS (Council for international Organizations of Medical Sciences) established by UNESCO (United Nations Educational, Scientific and Cultural Organization) and WHO (World Health Organization) 1949 and the Law 84 from October 27, 1989 (Colombian Animal Protection Statute) (21).

Statistical analysis. The data were tabulated and analyzed descriptively, and the statistical differences in the results of liver and kidney function tests of DFS animals with clinically healthy ones and the chi-square test was used, using S.A.S Software 9.1.3.

\section{RESULTS}

The observed clinical manifestations, anatomopathological characteristics of the lesions, and the results of histopathological and serological tests confirmed the DFS diagnosis in the 12 cattle studied according to what is reported as a diagnostic method for DFS in ruminants $(2,9,10,12$ 14). All calves had lesions on ears, chin, neck, chest and epigastric, perineal and inguinal regions, and all had mucosa with some degree of jaundice, dehydration and emaciation (Figure 1). aplicó un corticoide a base de dexametasona a dosis de $0.1 \mathrm{mg} / \mathrm{Kg}$ vía intramuscular y 10 centímetros de un multivitamínico comercial a base de complejo B vía intramuscular por 5 días, así mismo, se le administró a voluntad una solución de bebida hidratante consistente en una mezcla de melaza con adición de bicarbonato de sodio.

Aspectos éticos. Los animales no fueron sometidos a dolor y/o estrés innecesario, por lo que fueron inmovilizados teniendo en cuenta las normas técnicas en el manejo y sujeción de animales, enmarcado en el cumplimiento de la Declaración Universal de los Derechos de los Animales, referente a los principios éticos internacionales para la investigación biomédica con animales del CIOMS (Council for International Organizations of Medical Sciences) establecida por la UNESCO (United Nations Educational, Scientific and Cultural Organization) y la OMS (Organización Mundial de la Salud) de 1949 y de la Ley 84 de Octubre 27 de 1989 (Estatuto Colombiano de Protección Animal) (21).

Análisis estadístico. Los datos fueron tabulados y analizados en forma descriptiva, y la diferencia estadística de los resultados de las pruebas de funcionamiento hepático y renal entre los animales con DFS y los clínicamente sanos se utilizó la prueba de Chí cuadrado, utilizando el Software S.A.S 9.1.3.

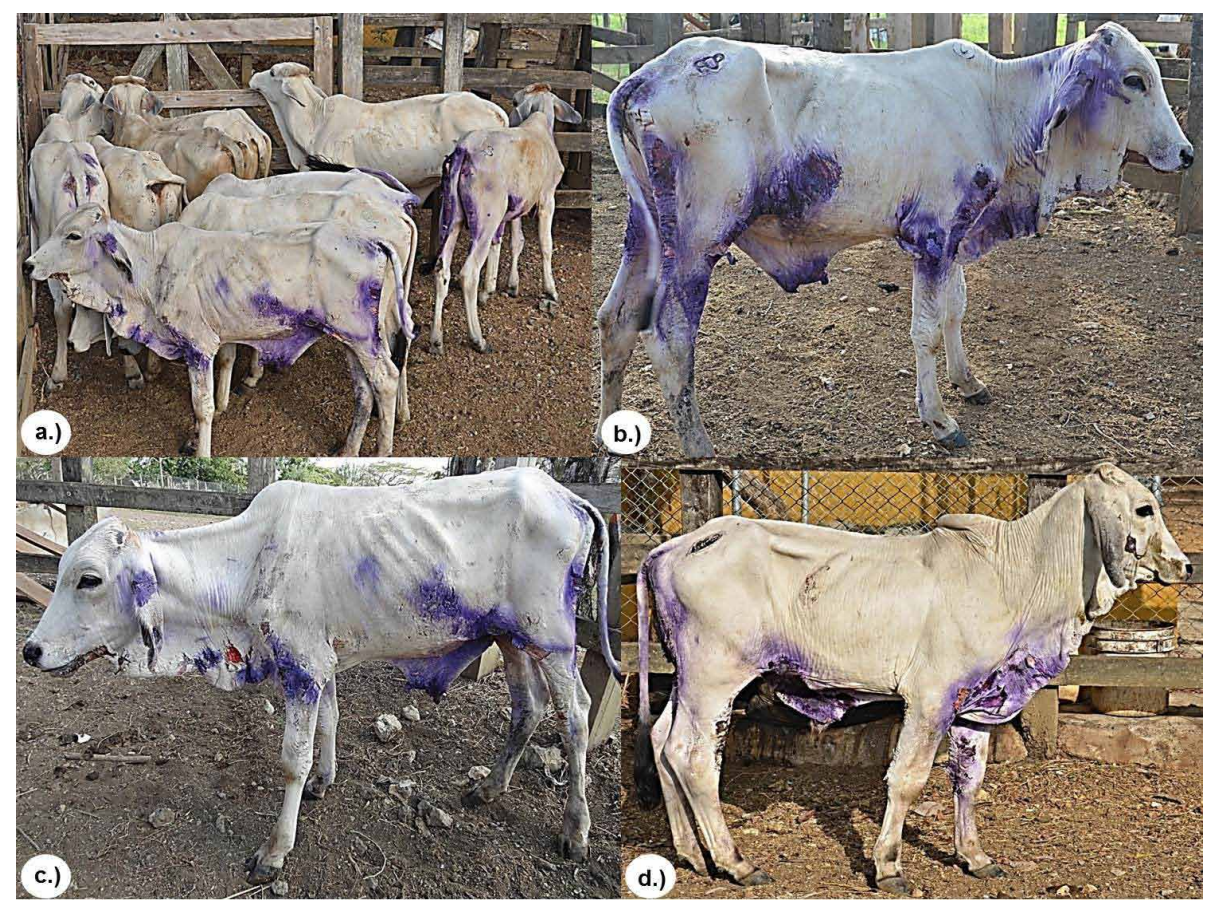

Figure 1. a.) Group of animals with DFS. a.), b.) and c.) Skin lesions on ears, chin, neck, thorax, and epigastric, perineal and inguinal regions, all with a loss of health. 
Clinical manifestations of skin lesions were characterized by the presence of erythema, edema, cracked skin with a leathery appearance and skin peeling in some areas with scabbing (Figure 2).

Table 1 shows the results of liver function tests (GGT and ALT) and renal function (urea and creatinine), of which only the hepatic enzymes of animals with DF showed considerably elevated catalytic activity, with statistically significant differences $(p<0.05)$ with respect to the catalytic activity of liver enzymes in the group of clinically healthy animals. Urea and creatinine concentrations in blood were within normal parameters for the group with DFS and the clinically healthy group taken as control.

Table 1. Serum values of GGT, AST, urea and creatinine in a group of calves with DFS and the clinically healthy group in that grazed on Brachiaria decumbens in the Department of Córdoba, Colombia.

\begin{tabular}{|c|c|c|c|c|c|}
\hline \multicolumn{2}{|c|}{$\begin{array}{c}\text { Variable (*) } \\
\text { ANIMALS }\end{array}$} & \multirow{2}{*}{$\begin{array}{c}\begin{array}{c}\text { GGT } \\
(\mathbf{U} / \mathbf{L})\end{array} \\
(\mathbf{6 , 1 - 1 7 , 4 )} \\
275.6\end{array}$} & \multirow{2}{*}{$\begin{array}{c}\begin{array}{c}\text { AST } \\
(\mathbf{U} / L)\end{array} \\
(\mathbf{7 8 - 1 3 2 )}\end{array}$} & \multirow{2}{*}{$\begin{array}{c}\begin{array}{c}\text { UREA } \\
(\mathbf{m g} / \mathbf{d L})\end{array} \\
(\mathbf{2 3 - 5 8 )}\end{array}$} & \multirow{2}{*}{$\begin{array}{c}\text { CREATININE } \\
\begin{array}{c}\text { (mg/dL) } \\
(\mathbf{1}-2)\end{array} \\
2.3\end{array}$} \\
\hline \multirow{12}{*}{ DFS } & 1 & & & & \\
\hline & 2 & 129.3 & 230.0 & 38.0 & 0.95 \\
\hline & 3 & 117.0 & 223.0 & 34.0 & 1.2 \\
\hline & 4 & 294.0 & 81.2 & 38.5 & 1.8 \\
\hline & 5 & 158.0 & 33.9 & 34.2 & 0.8 \\
\hline & 6 & 174.0 & 35.0 & 35.8 & 1.35 \\
\hline & 7 & 116.6 & 232.0 & 33.0 & 0.91 \\
\hline & 8 & 170.4 & 210.0 & 28.0 & 1.3 \\
\hline & 9 & 111.3 & 190.0 & 48.6 & 1.7 \\
\hline & 10 & 140.5 & 215.0 & 42.6 & 1.9 \\
\hline & 11 & 180.3 & 250.0 & 32.0 & 1.6 \\
\hline & 12 & 132.6 & 235.0 & 35.0 & 1.5 \\
\hline \multicolumn{2}{|c|}{ Mean \pm D.E } & $\begin{array}{l}166.6 \\
\pm 60.1\end{array}$ & $\begin{array}{l}187.5 \\
\pm 88.9\end{array}$ & $\begin{array}{c}39.4 \\
\pm 11.8\end{array}$ & $\begin{array}{c}1.4 \\
\pm 0.4\end{array}$ \\
\hline \multirow{6}{*}{ HEALTHY } & 1 & 17.0 & 38.3 & 40.0 & 0.9 \\
\hline & 2 & 21.3 & 45.2 & 32.0 & 1.8 \\
\hline & 3 & 23.3 & 35.3 & 46.0 & 2.0 \\
\hline & 4 & 14.0 & 40.1 & 27.0 & 0.8 \\
\hline & 5 & 12.0 & 23.7 & 21.0 & 0.7 \\
\hline & 6 & 18.6 & 22.8 & 20.0 & 1.9 \\
\hline \multicolumn{2}{|c|}{ Mean \pm D.E } & $\begin{array}{l}17.7 \\
\pm 4.3\end{array}$ & $\begin{array}{l}34.2 \\
\pm 9.1\end{array}$ & $\begin{array}{c}31.0 \\
\pm 10.4\end{array}$ & $\begin{array}{c}1.4 \\
\pm 0.6\end{array}$ \\
\hline
\end{tabular}

* Reference values according to Oliveira et al (9).

In all biopsies of skin tissue stained with the H\&E stain, similar histopathologic characteristics were observed that consisted of extensive clotting necrosis in the epidermal layer containing cellular debris and basophilic material resembling bacterial colonies, a large number of inflammatory mononuclear cells, macrophages and neutrophils, as well as epithelial degeneration with hyperkeratosis, disorganization of fibroblasts and fibrous connective tissue (Figure 3 ). In the T\&G stain, poor dermal proliferation of disorganized fibroblasts, low presence of diffuse connective tissue, and disorganized collagen fibers (Figure 4) were observed and in the P-R/P stain areas of birefringence were observed, indicating a moderate presence of mature type I collagen (bright red in polarization) and type III (bright green in polarization), (Figure 5).

\section{RESULTADOS}

Las manifestaciones clínicas observadas, las características anatomopatológicas de las lesiones, los resultados de las pruebas serológicas e histopatológicas confirmaron el diagnóstico de DFS en 12 bovinos estudiados de acuerdo con lo reportado como método diagnóstico de la DFS en rumiantes $(2,9,10,12,14)$. Todos los terneros presentaron lesiones a nivel de orejas, papada, cuello, tórax y región epigástrica, inguinal y perineal, así mismo, todos presentaron mucosas con algún grado de ictericia, deshidratación y enflaquecimiento (Figura 1).

Las manifestaciones clínicas de las lesiones cutáneas se caracterizaron por la presencia de eritema, edema, res-quebramiento de la piel con aspecto apergaminado, así como desprendimiento cutáneo en algunas áreas con formación de costra (Figura 2).

En la tabla 1 se pueden observar los resultados de las pruebas de funcionamiento hepático (GGT y $A L T$ ) y de funcionamiento renal (urea y creatinina), de las cuales sólo las enzimas hepáticas en los animales con DFS, presentaron actividad catalítica considerablemente elevadas, mostrando diferencias estadísticamente significativas $(p<0.05)$ con respecto a la actividad catalítica de las enzimas hepáticas del grupo de animales clínicamente sanos. Las concentraciones sanguíneas de urea y creatinina se encontraron dentro de los parámetros normales para el grupo con DFS y el grupo clínicamente sano tomado como control.

En todas las biopsias de tejido cutáneo teñidas con la coloración de $\mathrm{H}-\mathrm{E}$, se observaron características histopatológicas similares entre ellas, las cuales consistieron en presencia de necrosis de coagulación extensa en la capa epidérmica conteniendo desechos celulares y material basófilo que se asemeja a colonias bacterianas, gran cantidad de células inflamatorias de tipo mononuclear, macrófagos y neutrófilos, así como degeneración epitelial con hiperqueratosis, desorganización de fibroblastos y tejido conjuntivo fibroso (Figura 3). En la coloración de T-G, se observó escasa proliferación dérmica de fibroblastos desorganizados, escasa presencia de tejido conjuntivo difuso y fibras de colágeno desorganizadas (Figura 4) y en la coloración de $\mathrm{P}-\mathrm{R} / \mathrm{P}$, se observó áreas de birrefringencia, indicando moderada presencia de colágeno maduro tipo I (color rojo brillante en la polarización) y de tipo III (color verde brillante en la polarización), (Figura 5).

Todos los animales se recuperaron entre 30 y 40 días post inicio del tratamiento, por lo que no se cuentan con datos de necropsia, ni de 


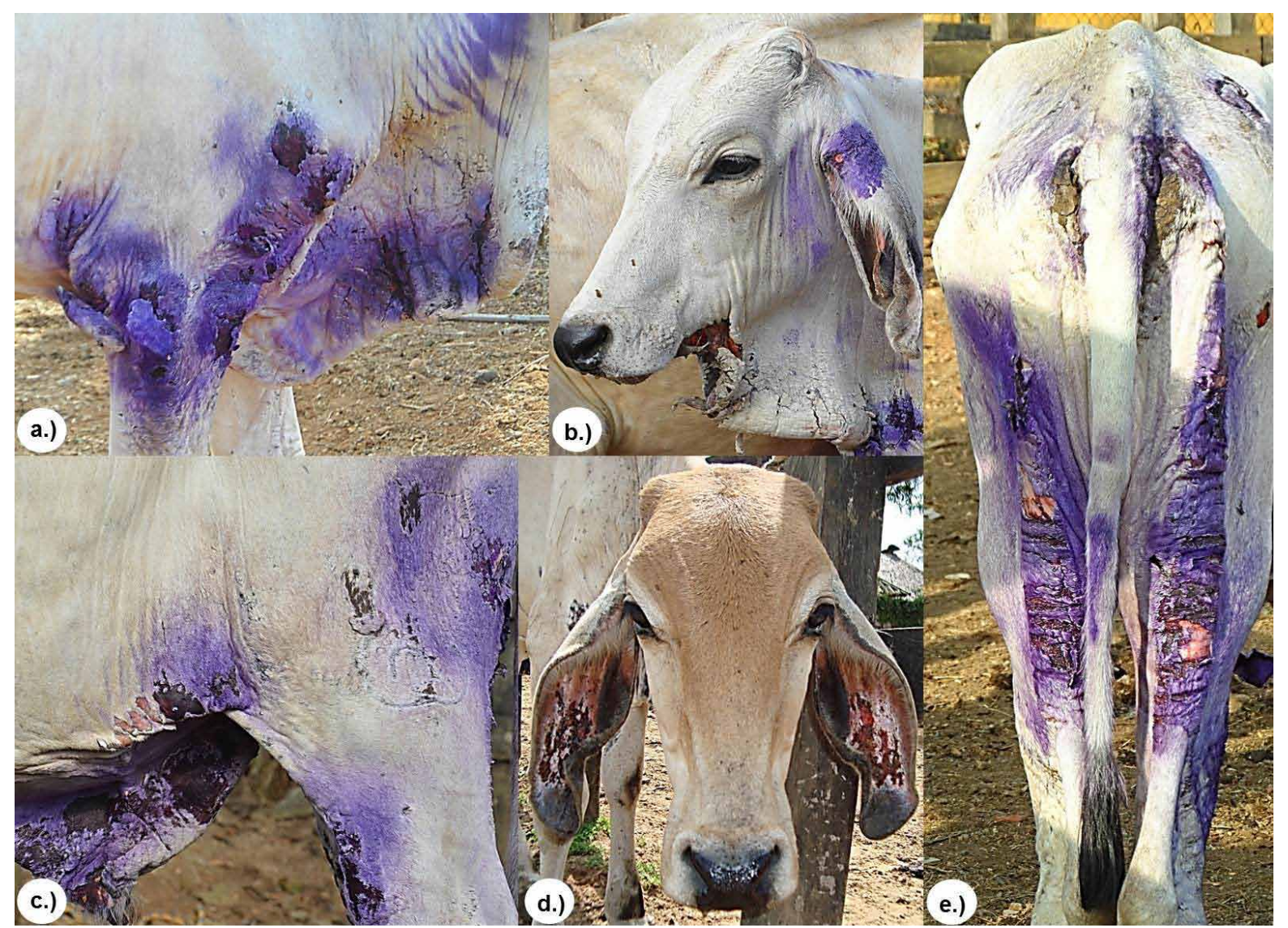

Figure 2. Clinical manifestations of cutaneous lesions characterized by the presence of erythema, edema, cracked skin with a shriveled appearance and skin peeling in some areas with scabbing at a.) shoulder and elbow, b.) dewlap c.) inguinal region and foreskin, d.) ears and e.) perineal and posterior region of pelvic areas.
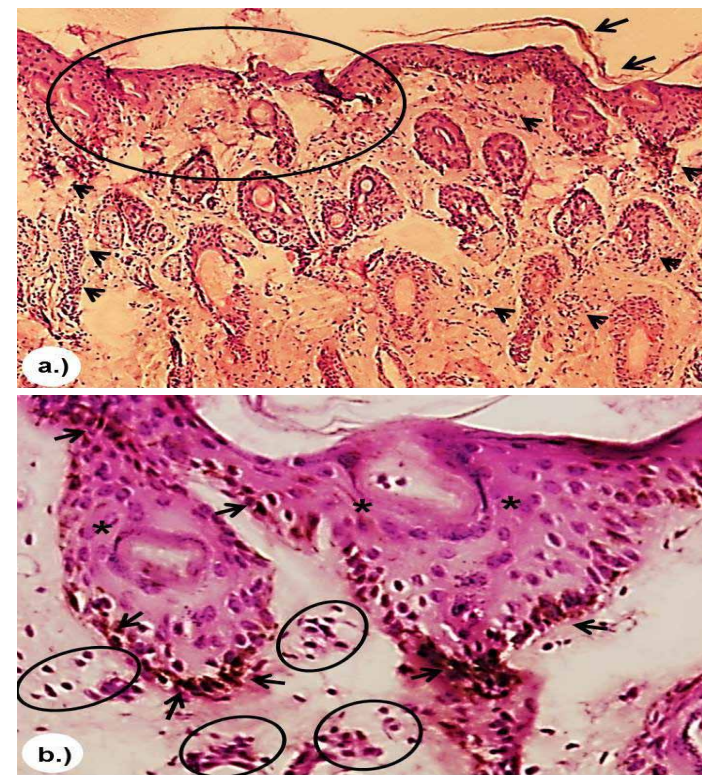

Figure 3. H\&E stain. a.) Presence of a large amount of neutrophilic PMN inflammatory cells (arrow) as well as marked epithelial degeneration (circle) with hyperkeratosis (arrow) 4x. b.) Presence of acantholytic cells in the granular layer (arrow), neutrophilic PMN (circle) and acantholysis (asterisk) 10x.

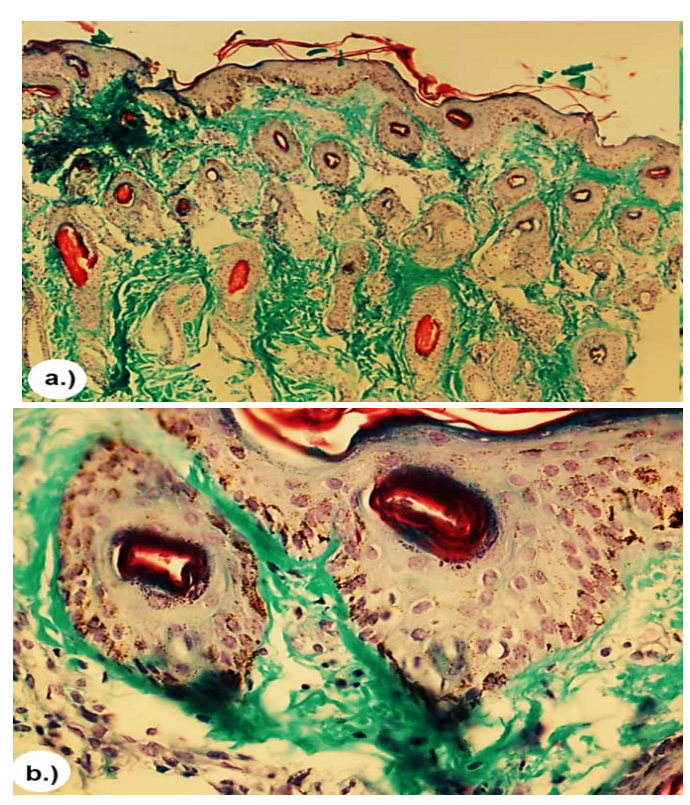

Figure 4. T\&G stain. Moderate dermal proliferation of disorganized and diffuse collagen fibers (green). a.) 4x. b.) 10x. 


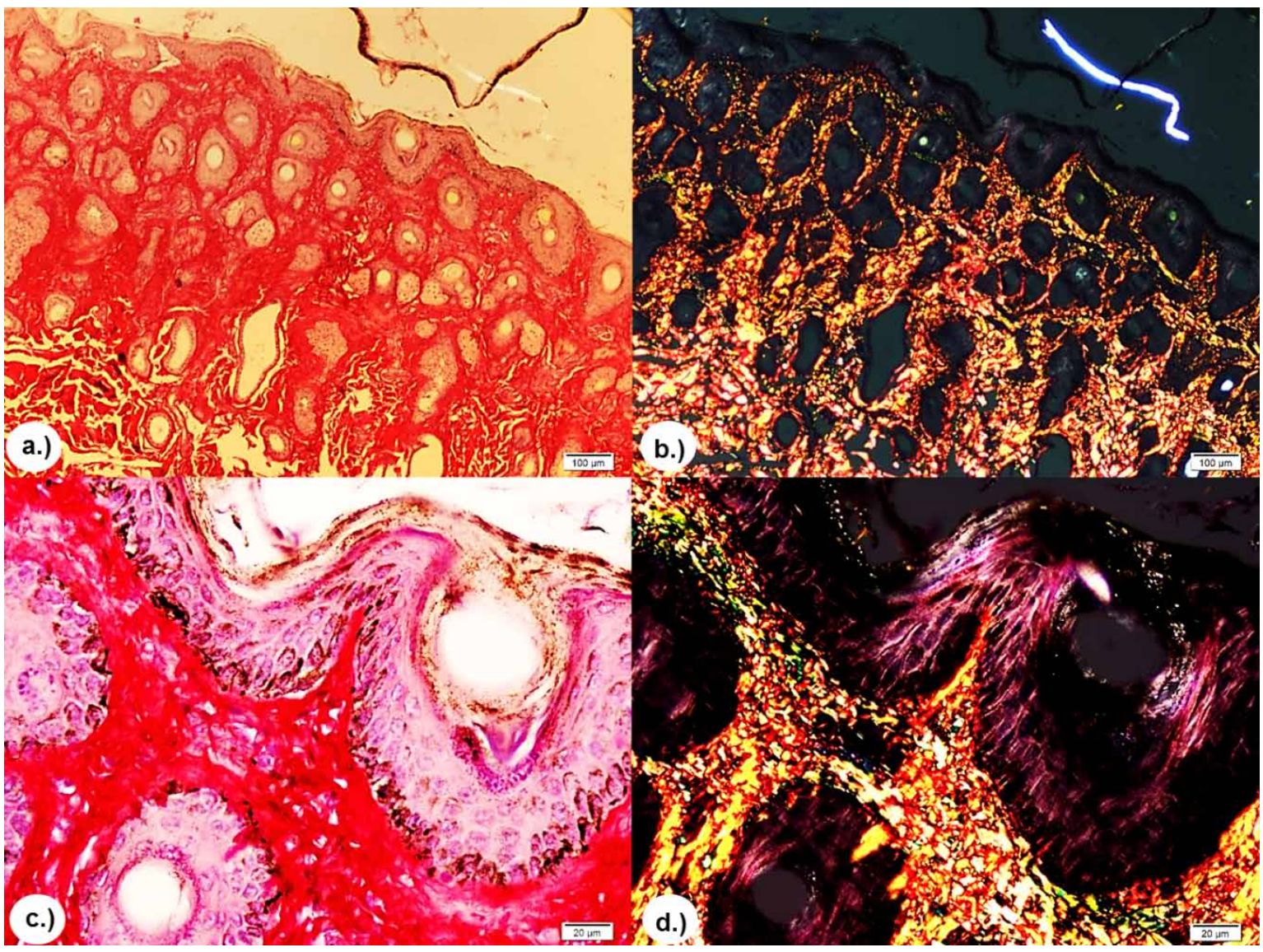

Figure 5. $P-R / P$ stain without polarization and with polarization, respectively. Showing areas of reddish and yellowishgreen birefringence indicating moderate presence of mature collagen type I (bright red in polarization) and type III (bright green-yellow in polarization). a.) and b.) 4X. c.) and d.) 10X.

All animals recovered 30 to 40 days after initiation of treatment, so there is no necropsy or hepatic histopathology data, and it was not possible to achieve special "Tru-Cut" needles to perform liver biopsies.

\section{DISCUSSION}

There are no reports in consulted literature on secondary phototoxic dermatitis in cattle in the department of Córdoba and Colombia that provide data on the time of year, type of Brachiaria in these cases, age at onset, duration of exposure and characterization of lesions, so this report is an important contribution to the knowledge of the disease in the region and the country.

DFS caused by Brachiaria spp. is likely to be sub-reported either for mortality or treatments by owners or operators. However, it is a major cause of damages that have a great economic impact on production systems around the world, especially in Brazil where histopatología hepática, ya que no fue posible la consecución de agujas "Tru-Cut" especiales para biopsias hepáticas.

\section{DISCUSIÓN}

No existen reportes en la literatura consultada sobre dermatitis fototóxica secundaria en bovinos del departamento de Córdoba y Colombia, que aporten datos sobre la época del año, tipo de Brachiaria en la que se presentan los casos, edad de presentación, tiempo de exposición y caracterización de las lesiones, por lo que el presente reporte constituye un aporte importante al conocimiento de la enfermedad en la región y el país.

La DFS causada por Brachiaria spp., es muy probable que su presentación sea sub-notificada ya sea por mortalidad o tratamientos realizados por propietarios u operarios; sin embargo, es una importante causa de prejuicios de gran impacto económico en los sistemas productivos de diferentes partes del mundo, especialmente en estados de 
the majority reports and research has been done (22). Therefore, economic losses can be direct in the case of death of an animal with DFS or in decreased production rates (abortions, infertility, loss of weight or milk, meat, etc.) or indirectly due additional pasture management strategies, fence utilization for rotational grazing, reduction of pasture quality by delaying use, replacement of dead animals and expensive treatments (23).

The most common clinical signs were photophobia, edema around the eyes and chin, cracking, peeling and scabbing of skin around ears, lower jaw, perineal, costal and inguinal regions and progressive emaciation. All these are similar to those described by Mustafa et al (1), Sant'Ana et al (2), Riet-Correa et al $(7,8)$, Oliveira et al (9), Souza et al (10), Albernaz et al (11), Quinn et al (12), and Faccin et al (14). Lesions were located at sites of increased exposure to sunlight according to what was reported by Sant'Ana et al (2) and Oliveira et al (9); however, Porto et al (5) expressed that sun exposure does not determine the presentation of clinical signs of intoxication but exacerbates clinical symptoms in affected animals.

Riet-Correa et al (7), show that progressive emaciation is due to malabsorption associated with the presence of foamy macrophages in the intestinal mucosa, which leads to weight loss. Jaundice observed in the clinical examination is a sign of hepatoxic injury caused by ingestion of Braquiaria and was confirmed by increased AST and GGT serum activity due to extravasation of bile pigments from bile ducts obstructed by crystals formed by conjugating saponin with calcium $(7,18)$. Keratitis and blindness were not observed in the calves studied as clinical signs of $B$. decumbens poisoning, as reported by Albernaz et al (11) in sheep poisoned by $B$. brizantha in the state of Pará (Brazil).

The high catalytic activity of liver enzymes is consistent with what was reported by Mustafa et al (1), Sant'Ana et al (2), Porto et al (5), Riet-Correa et al (7), Oliveira et al (9), Souza et al (10), Albernaz et al (11) and Faccin et al (14), who found that animals with DFS manifest skin lesions and present a sharp rise in AST and GGT liver enzymes, indicating that this finding is of great diagnostic value for liver injuries in animals poisoned by Brachiaria spp. grasses. Similarly, they explain that GGT is an enzyme that exhibits increased activity in liver diseases associated with cholestasis since it is linked to cells membranes and is mainly
Brasil donde se han realizado la mayor cantidad de reportes e investigaciones (22), es así como las pérdidas económicas pueden ser directas en casos de muerte del animal con DFS o disminución de los índices productivos (abortos, infertilidad, pérdida de peso o leche, carne, etc), o de forma indirecta debido a la inclusión de estrategias adicionales en el manejo de pasturas, utilización de cercas para el pastoreo rotacional, reducción de la calidad del pasto al retrasar su utilización, reemplazo de los animales muertos o tratamientos costosos de los afectados (23).

Los signos clínicos más frecuentes fueron, fotofobia, edema alrededor de los ojos y papada, resquebramiento, desprendimiento y formación de costras de la piel a nivel de orejas, mandíbula inferior, región perineal, costal e inguinal, así como enflaquecimiento progresivo, siendo semejantes a los descritos por Mustafa et al (1), Sant'Ana et al (2), Riet-Correa et al $(7,8)$, Oliveira et al $(9)$, Souza et al (10), Albernaz et al (11), Quinn et al (12), Faccin et al (14), Las lesiones se ubicaron en sitios de mayor exposición a los rayos solares concordando con lo reportado por Sant'Ana et al (2) y Oliveira et al (9); sin embargo, Porto et al (5), expresan que la exposición solar no determina la presentación de signos clínicos de intoxicación, pero sí exacerba el cuadro clínico en los animales intoxicados.

Riet-Correa et al (7), manifiestan que el enflaquecimiento progresivo se debe al síndrome de mala absorción asociada a la presencia de macrófagos espumosos en la mucosa intestinal, lo que conlleva a pérdida de peso. La icterícia observada en el examen clínico es señal de lesión hepatóxica producida por la ingestión de Braquiária y confirmada por los aumentos de las actividades séricas de AST y GGT, debido al extravasamiento de pigmentos biliares provenientes de la obstrucción de los ductos biliares por cristales formados por la conjugación de la saponina con el calcio $(7,18)$. Queratitis y ceguera no fueron observados en los terneros del estudio como signos clínicos de la intoxicación por $B$. decumbens, como fue reportado por Albernaz et al (11) en ovinos intoxicados por $B$. brizantha en el estado de Pará (Brasil).

La elevada actividad catalítica de las enzimas hepáticas, concuerda con lo informado por Mustafa et al (1), Sant'Ana et al (2), Porto et al (5), Riet-Correa et al (7), Oliveira et al (9), Souza et al (10), Albernaz et al (11) y Faccin et al (14), quienes determinaron que en los animales con DFS que manifiesten lesión de piel presentan aumento acentuado de las enzimas hepáticas AST y GGT, indicando que este hallazgo es de gran valor diagnóstico de lesión hepática de animales intoxicados por gramíneas del género Brachiaria spp., de igual forma explican que la GGT es una 
located in canaliculi, bile ducts, and to a lesser extent in hepatocytes and is released when there these structures are damaged. Similarly, Gracindo et al (6) and Faccin et al (14) reported in their study that the mean serum catalytic activity of GGT in sheep that grazed on $B$. decumbens was higher than sheep that grazed in paddocks with other grass.

Clinical manifestations and mortality in cases of poisoning by Brachiaria spp. depend on factors related to the plant and factors associated with susceptibility or resistance of the animal (8). According to what has been observed, sheep grazing on Brachiaria spp. can have high GGT elevations without presenting clinical manifestations of intoxication (24), suggesting that are resistant to poisoning with subclinical or absent expression (7). Therefore, the level of GGT activity is considered a good indicator of Brachiaria spp. poisoning. As was demonstrated, greater GGT activity in animals never exposed than those exposed for long periods to Brachiaria spp. pasture suggests GGT can be a good indicator of resistance, and similarly, high concentrations of GGT without clinical signs of toxicity in animals exposed for long periods to pasture $(7,8)$. Therefore, a way to increase resistance in the flock is eliminating animals that exhibit clinical signs of the disease or by monitoring GGT concentrations in exposed individuals $(5,14)$.

Histopathologic findings of this study with the H\&E stain correspond to those reported in literature to diagnose DFS $(4,5,14)$, especially in foci of necrosis of the epidermal layer, neutrophilic infiltration and hyperkeratosis. Similarly, in the T\&G strain, the presence of diffuse connective tissue with small areas of poor dermal fibroblast proliferation and the presence of disorganized collagen fibers was evident. Also, in the P-R/P stain small areas of red and yellow-green birefringence were observed, indicating a moderate presence of mature collagen type I and type III, which could indicate moderate regenerative response against aggression phototoxic process. These techniques have been used as a response indicator of skin repair in aggressive skin states (25). However, it is necessary to clarify that there are no reports of the use of histochemical techniques such as T\&G and $\mathrm{P}-\mathrm{R} / \mathrm{P}$ to diagnose and prognosis of DFS in cattle.

The calves in the study were between 12 and 18 months of age, coinciding with what enzima que presenta actividad aumentada en enfermedades hepáticas asociadas con colestasis, debido a que está ligada a la membrana de las células y se localiza principalmente en canalículos, ductos biliares y en menor grado en los hepatocitos y es liberada cuando hay daño en estas estructuras. De igual forma, Gracindo et al (6) y Faccin et al (14), reportaron en su estudio que la media en suero de la actividad catalítica de GGT en las ovejas que pastaron en $B$. decumbens fue más alta que la de las ovejas que pastaron en potreros con otro tipo de pasto.

Las manifestaciones clínicas y la mortalidad en casos de intoxicación por Brachiaria spp., depende de factores relacionados con la planta y en factores relacionados con la susceptibilidad o resistencia del animal (8). Por lo que se ha observado que las ovejas que pastan en Brachiaria spp., pueden tener grandes elevaciones de GGT sin presentar manifestaciones clínicas de intoxicación (24), lo que sugiere que son resistentes a la intoxicación, con expresión subclínica o ausente (7). Por lo tanto el nivel de actividad de la GGT es considerado un buen indicador de intoxicación por Brachiaria spp., ya que fue demostrado mayor actividad de GGT en animales nunca expuestos que los si expuesto por largos periodos a pastos Brachiaria spp., lo que sugiere que la GGT puede ser un buen indicador de la resistencia, de igual forma, elevadas concentraciones de GGT sin signos clínicos de toxicidad en animales expuestos por largos períodos al pasto $(7,8)$, por lo tanto, una forma de aumentar la resistencia del rebaño es la eliminación de los animales que manifiestan signos clínicos de la enfermedad o mediante selección monitoreando las concentraciones de GGT en individuos expuestos $(5,14)$.

Los hallazgos histopatológicos del presente estudio con la coloración de $\mathrm{H}-\mathrm{E}$, se corresponden con los reportados en la literatura para el diagnóstico del DFS $(4,5,14)$, especialmente en los focos de necrosis de la capa epidérmica, en la infiltración neutrofílica y la hiperqueratosis. De igual forma en la coloración de T-G, se evidenció la presencia de tejido conjuntivo difuso, con pequeñas áreas de escasa proliferación dérmica de fibroblastos y presencia de fibras de colágeno desorganizadas. Asimismo, en la coloración de $\mathrm{P}-\mathrm{R} / \mathrm{P}$, se observaron pequeñas áreas de birrefringencia rojiza y verde amarilla, indicando presencia moderada de colágeno maduro tipo I y tipo III; lo que podría indicar moderada respuesta regenerativa del organismo frente al proceso de agresión fototóxica. Estás técnicas han sido utilizadas como indicador del grado de respuesta de reparación en estados agresivos cutáneos (25). Sin embargo, es preciso aclarar que no existen reportes del uso de técnicas histoquímicas como T-G y P-R/P como apoyo diagnóstico y pronóstico del DFS en bovinos. 
by Souza et al (10) reported, who grouped photosensitizing animals in that age range, and in a similar manner Sant'Ana et al (2) reported greater presentation in calves between 4 and 14 months and a lesser tendency in adult cattle.

The animals recovered 30 and 40 days after initiating the treatment strategy, which agrees with Gracindo et al (6) who reported that recovery time of the affected cattle was between 15 and 45 days after being removed from the areas with Brachiaria spp.; however, it states that it is likely that the animals have cutaneous scars until slaughter.

From a toxicological point of view, Brachiaria is often classified as a toxic photosensitizing plant (26), since all Brachiaria have shown some degree of toxicity. In his study Sant'Ana et al (2) found greater poisoning outbreaks with Brachiaria in grazing on $B$. decumbens, followed by $B$. brizantha and $B$. humidicola in minor proportions, coinciding with that reported by Riet-Correa et al (7), who showed that $B$. decumbens has a higher concentration of saponins than $B$. brizantha and $B$. humidicola.

The group of affected calves came from areas free of Brachiaria and were put to graze in a pasture that had been planted 2 months prior with Brachiaria decumbens, which may be a risk factor for the outbreak, consistent with that reported by Gracindo et to (6) and Lima et al (27), who found higher mean values of protodioscin saponin at 60 days in $B$. decumbens, indicating that young plants contain four times more saponin protodioscin than old and mature plants. Some outbreaks of DFS occur when animals are placed in paddocks that have been unused for some time, after the rainy season or during the period of regrowth as happened in the months in which the study was conducted, which coincides with the first rains on the northern coast of Colombia. However, Brum et al (28) show that the highest concentrations of protodioscin saponins are found in the maturation phase of Brachiaria, coinciding with the fall of seeds.

Because of the importance of Brachiaria $s p p$. in many regions in tropical countries for its nutritious excellence as forage and its ability to grow in more rugged terrain, it is very important to establish preventive practices and measures to control toxicity using less toxic Brachiarias varieties with decreased protodioscin concentration than $B$. decumbens $(1,7,27)$. Similarly, the use of resistant
Los terneros del estudio tenían entre 12 y 18 meses de edad, coincidiendo con lo informado por Souza et al (10), quienes grupos de animales con fotosensibilización en ese rango de edades, de igual forma Sant'Ana et al (2), reportó mayor presentación en terneros entre 4 y 14 meses y menor presentación en bovinos adultos.

Los animales se recuperaron entre 30 y 40 días después de iniciada la estrategia terapéutica, concordando con Gracindo et al (6), quienes informaron que el tiempo de recuperación de los bovinos afectados oscila entre 15 y 45 días después de ser retirados de las áreas con Brachiaria spp.; sin embargo, expresa que es probable que los animales queden con cicatrices cutáneas de las lesiones hasta el sacrificio.

Desde el punto de vista toxicológico, las Brachiarias son frecuentemente clasificada como planta tóxica fotosensibilizante (26), siendo que todas las Brachiarias han demostrado algún grado de toxicidad, es así como Sant'Ana et al (2), en su estudio encontró mayor presentación de brotes de intoxicación con Brachiarias en pastoreos de $B$. decumbens, seguido de $B$. brizantha y $B$. humidicula en menores proporciones, coincidiendo con lo informado por Riet-Correa et al (7), quienes demostraron que $B$. decumbens tiene una mayor concentración de saponinas que $B$. brizantha y $B$. humidicola.

El grupo de terneros afectados procedía de zonas sin Brachiaria, y fueron colocados a pastar en un potrero que tenía 2 meses de haber sido sembrado con Brachiaria decumbens, pudiendo ser un factor de riesgo para la presentación del brote, concordando con lo reportado por Gracindo et al (6) y Lima et al (27), quienes encontraron valores medios de saponina protodioscina más elevados a los 60 días en $B$. decumbens, indicando que las plantas jóvenes contienen cuatro veces más saponina protodioscina que plantas maduras y viejas, por lo que algunos brotes de DFS ocurren cuando los animales son colocados en potreros que llevan algún tiempo sin utilización, después de la temporada de lluvias o en el periodo de rebrote del pasto como sucedió en los meses en los cuales se realizó el estudio, que coincide con las primeras lluvias en la costa norte de Colombia. Sin embargo, Brum et al (28), manifiestan que las mayores concentraciones de saponinas protodioscina se encuentran en la fase de maduración de la Brachiaria, coincidiendo con la caída de semillas.

Debido a la importancia de la Brachiaria spp., en la gran parte de regiones en países tropicales por su excelencia nutritiva y forrajera, así como su capacidad de crecimiento en terrenos más agrestes, se hace muy importante establecer prácticas preventivas y medidas de control de la toxicidad, mediante el uso de variedades de Brachiarias menos tóxicas con menor concentración de protodioscinas que la $B$. 
animals is recommended by selecting those that did not have signs or that maintained liver enzyme levels in the normal range for the species.

In conclusion, the clinical features of skin lesions were consistent with the results of serological tests and histopathological findings in twelve cattle in the department of Córdoba with the presence of DFS. It is an important contribution to confirm accurate diagnosis of pathological conditions and to warn about the presentation of the disease and the need for further studies on this pathological condition in areas where only Brachiaria spp. is available, and its effects on cattle in the region. decumbens $(1,7,27)$, de igual forma, es recomendable el uso de animales resistentes mediante selección de aquellos que no expresaron signos o que mantuvieron concentraciones de enzimas hepáticas en los rangos normales para la especie.

En conclusión las características clínicas de las lesiones cutáneas concordaron con los resultados de las pruebas serológicas y los hallazgos histopatológicos encontrados en doce bovinos del departamento de Córdoba con presencia de DFS; siendo un aporte importante para el diagnóstico certero de la condición patológica, por lo que se advierte sobre la presentación de la enfermedad y la necesidad de realizar más estudios sobre esta condición patológica en zonas donde sólo tienen cultivos de pasto Brachiaria spp., y sus efectos en los bovinos de la región.

\section{REFERENCES}

1. Mustafa V, Moscardini A, Borges J, Reckziegel G, Riet-Correa F, Castro M. Caracterização da intoxicação natural por Brachiaria spp em ovinos no Brasil Central. Pesq Vet Bras 2012; 32(12):1272-1280.

2. Sant'Ana F, Reis-Jr J, Neto A, Moreira-Jr C, Vulcani V, Rabelo R, Terra. Plantas tóxicas para ruminantes do Sudoeste de Goiás. Ciênc Rural 2014; 44(5):865-871.

3. Benavides E, López M, Alayón L. Enfermedades del ganado en la región de La Macarena (Meta). Un ejercicio de epidemiología participativa. Rev Med Vet 2011; 21:41-62.

4. Ocal N, Haydardedeoğlu A, Cinar M, Kul O, Türk M. Hepatogenous photosensitization in Akkaraman lambs: special emphasis to oxidative stress and thrombocytopenia. Ankara Üniv Vet Fak Derg 2013; 60:117-122.

5. Porto M, Saturnino K, Lima E, Lee S, Lemos $\mathrm{R}$, Marcolongo-Pereira C, Riet-Correa $\mathrm{F}$, Castro M. Avaliação da exposição solar na intoxicação experimental por Brachiaria decumbens em ovinos. Pesq Vet Bras 2013; 33(8):1009-1015.

6. Gracindo C, Louvandini H, Riet-Correa F, Barbosa-Ferreira M, Castro M. Performance of sheep grazing in pastures of Brachiaria decumbens, Brachiaria brizantha, Panicum maximum, and Andropogon gayanus with different protodioscina concentrations. Trop Anim Health Prod 2014; 46:733-737.
7. Riet- Correa B, Castro M, Lemos R, Riet-Correa G, Mustafa V, Riet-Correa F. Brachiaria spp. poisoning of ruminants in Brazil. Pesq Vet Bras 2011; 31(3):183-192.

8. Riet-Correa B, Riet-Correa F, Oliveira Junior C, Duarte V, Riet-Correa G. Alterações histológicas em fígados e linfonodos de búfalos (Bubalus bubalis) mantidos em pastagens de Brachiaria spp. Pesq Vet Bras 2010; 30(9):705-711.

9. Oliveira C, Barbosa J, Oliveira C, Bastianetto E, Melo M, Haraguchi M, Freitas L, Silva $M$, Leite R. Hepatic photosensitization in buffaloes intoxicated by Brachiaria decumbens in Minas Gerais state, Brazil. Toxicon 2013; 73:121-129.

10. Souza R, Riet-Correa F, Barbosa-Ferreira M, Brum K, Fernandes C, Lemos R. Intoxicação por Brachiaria spp. em bovinos no Mato Grosso do Sul. Pesq Vet Bras 2010; 30(12):1036-1042.

11. Albernaz T, Silveira J, Silva N, Oliveira C, Belo Reis A, Oliveira C, et al. Fotossensibilização em ovinos associada à ingestão de Brachiaria brizantha no estado do Pará. Pesq Vet Bras 2010; 30 (9):741-748.

12. Quinn J, Kessell A, Weston L. Secondary Plant Products Causing Photosensitization in Grazing Herbivores: Their Structure, Activity and Regulation. Int J Mol Sci 2014; 15:1441-1465. 
13. Borges L, Domingues M, Mattei S, Miyazawa $M$, Sincinetti J. Fotossensibilização secundária pela ingestão de Brachiária em bovino. Rev Cient Elet Med Vet [En línea] 2005 julio [Fecha de acceso 29 de abril de 2015]; 5. URL disponible en: http://faef.revista.inf. br/imagens arquivos/arquivos destaque/ rOxF86TzLRmHzEU 2013-5-20-11-13-55.pdf

14. Faccin $T$, Riet-Correa $F$, Rodrigues $F$, Santos $A$, Melo G, Silva J, et al. Poisoning by Brachiaria brizantha in flocks of naïve and experienced sheep. Toxicon 2014; 82:1-8.

15. Scheie E, Smith B, Cox N, Flaoyen A. Spectrofluorometric analysis of phylloerythrin (phytoporphyrin) in plasma and tissues from sheep suffering from facial eczema. $\mathrm{N} Z$ Vet J 2003; 51:104-110.

16. Barbosa J, Oliveira C, Tokarnia C, Peixoto P. Fotossensibilização hepatógena em eqüinos pela ingestão de Brachiaria humidicola (Gramineae) no Estado do Pará. Pesq Vet Bras 2006; 26(3):147-153.

17. Wina E, Muetzel S, Becker K. The impact of saponins or saponincontaining plant materials on ruminant productions: A review. J Agric Food Chem2005; 53:8093-8105.

18. Santos J, Riet-Correa F, Simões S, Barros C. Patogênese, sinais clínicos e patologia das doenças causadas por plantas hepatotóxicas em ruminantes e eqüinos no Brasil. Pesq Vet Bras 2008; 28(1):1-14.

19. Mendonça F, Camargo I, Freitas S, Dória R, Baratella-Evêncio I, Evêncio-Neto J. Aspectos clínicos e patológicos de um surto de fotossensibilização hepatógena em ovinos pela ingestão de Brachiaria decumbens (Gramineae) no município de Cuiabá, Mato Grosso. Ci An Bras 2008; 9(4): 1034-1041.

20. Pabón J, Eslava J, Gómez R. Generalidades de la distribución espacial y temporal de la temperatura del aire y de la precipitación en Colombia. Meteorol Colomb 2001; 4: 47-59.
21. Mrad A. Ética en la investigación con modelos animales experimentales. Alternativas y las 3 RS de Russel. Una responsabilidad y un compromiso ético que nos compete a todos. Rev Col Bioética 2006; 1(1):163-184.

22. Pessoa C, Medeiros R, Riet-Correa F. Importância econômica, epidemiologia e controle das intoxicações por plantas no Brasil. Pesq Vet Bras 2013; 33(6):752-758.

23. Assis T, Medeiros R, Riet-Correa F, Galiza G, Dantas A, Oliveira D. Intoxicações por plantas diagnosticadas em ruminantes e equinos e estimativa das perdas econômicas na Paraíba. Pesq Vet Bras 2010; 30(1):13-20.

24. Saturnino $K$, Mariani $T$, Barbosa-Ferreira $M$, Brum K, Fernandes C, Lemos R. Intoxicação experimental por Brachiaria decumbens em ovinos confinados. Pesq Vet Bras 2010; 30(3): 195-202.

25. Cardona J, Vargas M, Perdomo S. Estudio Clínico e Histopatológico del Carcinoma de Células Escamosas de Bovinos en el Departamento de Córdoba, Colombia. Rev Fac Cs Vets UCV 2013; 54 (2):68-77.

26. Riet-Correa F, Haraguchi M, Dantas A, Burakovas R, Medeiros R, Matos P. Sheep poisoning by Panicum dichotomiflorum in northeastern Brazil. Pesq Vet Bras 2009; 29(1):94-98.

27. Lima F, Lee S, Pfister J, Fioravanti M, RietCorrea F. Análise de saponina protodioscina por HPLC-ESI-MS em Brachiaria brizantha e Brachiaria decumbens durante 13 meses. Vet e Zootec 2011; 18(4 Supl. 3):576-579.

28. Brum K, Haraguchi M, Garutti M, Nóbrega F, Rosa B, Fioravanti M. Steroidal saponin concentrations in Brachiaria decumbens and $B$. brizantha at different developmental stages. Ci Rural 2009; 39(1):279-281. 